University of Nebraska - Lincoln

DigitalCommons@University of Nebraska - Lincoln

Agronomy \& Horticulture -- Faculty Publications

Agronomy and Horticulture Department

$11-1984$

\title{
Influence of Sample Treatment on Apparent Hydrocyanic Acid Potential of Sorghum Leaf Tissue
}

\author{
Francis A. Haskins \\ University of Nebraska-Lincoln, fhaskins@neb.rr.com \\ Herman J. Gorz \\ United States Department of Agriculture \\ R. M. Hill \\ University of Nebraska-Lincoln \\ J. Brakke Youngquist \\ University of Nebraska-Lincoln
}

Follow this and additional works at: https://digitalcommons.unl.edu/agronomyfacpub

Part of the Plant Sciences Commons

\begin{abstract}
Haskins, Francis A.; Gorz, Herman J.; Hill, R. M.; and Youngquist, J. Brakke, "Influence of Sample Treatment on Apparent Hydrocyanic Acid Potential of Sorghum Leaf Tissue" (1984). Agronomy \& Horticulture -- Faculty Publications. 270.

https://digitalcommons.unl.edu/agronomyfacpub/270
\end{abstract}

This Article is brought to you for free and open access by the Agronomy and Horticulture Department at DigitalCommons@University of Nebraska - Lincoln. It has been accepted for inclusion in Agronomy \& Horticulture -Faculty Publications by an authorized administrator of DigitalCommons@University of Nebraska - Lincoln. 


\title{
Influence of Sample Treatment on Apparent Hydrocyanic Acid Potential of Sorghum Leaf Tissue ${ }^{1}$
}

\author{
F. A. Haskins, H. J. Gorz, R. M. Hill, and J. Brakke Youngquist ${ }^{2}$
}

\begin{abstract}
When dhurrin [ $p$-hydroxy-(S)-mandelonitrile- $\beta$-D-glucoside], the cyanogenic glucoside of sorghum [Sorghum bicolor (L.) Moench], is hydrolyzed by autoclaving, $p$-hydroxybenzaldehyde $(p-\mathrm{HB})$ is released. The spectrophotometric determination of $p$ HB concentration in autoclaved sorghum leaf extracts provides a measure of the hydrocyanic acid potential (HCN-p) of leaf tissue. Extracts of field-grown sorghum leaves contained substances that interfered with this procedure, but ether extraction effectively separated $p$-HB from these interfering materials. We observed that when flag leaf tissue from field-grown sorghum was dried at $75^{\circ} \mathrm{C}$ and then autoclaved, $H C N$-p values were about three times as high as those based on tissue that was autoclaved without drying. Investigations of this apparent enhancement supported the conclusion that when fresh field-grown sorghum leaf tissue was autoclaved, dhurrin was extensively altered or lost, but neither $p$-HB nor HCN was produced. Drying the tissue at $75^{\circ} \mathrm{C}$ prior to autoclaving effectively reduced this loss. Inclusion of tissue drying and ether extraction steps in the spectrophotometric assay made this procedure, which was designed for use with sorghum seedlings, satisfactory for use with field-grown sorghum leaves.
\end{abstract}

Additional index words: Cyanogenesis, Dhurrin, p-Hydroxybenzaldehyde, Prussic acid, Sorghum bicolor (L.) Moench, Spectrophotometric assay.

A $\mathrm{N}$ earlier paper from this laboratory described a procedure for the spectrophotometric assay of the hydrocyanic acid potential (HCN-p) of young chamber-grown sorghum [Sorghum bicolor (L.) Moench] seedlings (2). The procedure was based on determination of $p$-hydroxybenzaldehyde $(p-\mathrm{HB})$ released when dhurrin [ $p$-hydroxy-(S)-mandelonitrile$\beta$-D-glucoside], the cyanogenic compound of sorghum, was autoclaved in water. The absorbance spectrum of $p$-HB in alkaline solution has a pronounced peak at $330 \mathrm{~nm}$. Autoclaved extracts of leaves from young seedlings displayed absorbance spectra very similar to that of pure $p$-HB (2); for such leaves $A_{330}$ values of extracts diluted in base, provided a reliable measure of $\mathrm{HCN}-\mathrm{p}(2,6)$. This seedling assay procedure was used successfully in a program of divergent selection for HCN-p in sudangrass [S. sudanense (Piper) Stapf] (3).

Absorbance spectra of extracts from young fieldgrown sorghum tillers differed appreciably from that of pure $p$-HB (6). Spectra of some tiller extracts lacked a 330-nm peak; those of other extracts had peaks at $330 \mathrm{~nm}$, but their shape suggested extensive non- $p$ $\mathrm{HB}$ absorbance at $330 \mathrm{~nm}$. Reliability of the spectrophotometric procedure for use with tillers was improved by fractionating the autoclaved tiller extracts with ether. The $p-\mathrm{HB}$ in these extracts was soluble in the ether phase whereas most of the interfering materials remained in the aqueous phase (5).

We have observed that when extracts obtained by autoclaving fresh field-grown sorghum flag leaves were diluted in base and scanned, the resulting spectra lacked well defined peaks at $330 \mathrm{~nm}$. However, spectra obtained from oven-dried samples had well defined $330-n m$ peaks. The objective of this study was to investigate the effects of leaf drying and other treatments on the spectra of leaf extracts and on the HCN-p values based on these spectra. In the course of these experiments, the spectrophotometric procedure for seedlings (2) was modified, making it satisfactory for use with field-grown sorghum leaves.

\section{MATERIALS AND METHODS Entries}

Unless specified otherwise, A-lines of KS8 and N32 sorghum were used in these experiments. KS8 was derived from a cross of 'White Martin' grain sorghum X 'Piper' sudangrass (10). N32 was selected from grain sorghum line SC102-9 (11). Grown and assayed as described previously (2), entire week-old shoots of both entries had HCN-p values of about $2200 \mathrm{mg} \mathrm{kg}^{-1}$ (dry basis).

\section{Leaf Tissue}

Upper leaves from field-grown plants were used. Samples taken prior to head emergence included the youngest leaf with a readily visible collar and, in some instances, the next one or two older leaves. Samples taken from headed plants included the flag leaf and the next one or two older leaves. Blades of the sampled leaves were excised, wrapped in moist paper towels, and carried to the laboratory where midribs were removed and discarded. The remaining tissue was cut into $1 \mathrm{~cm}^{2}$ pieces that were thoroughly mixed before random samples were withdrawn for treatment.

\section{Standard Assay}

The procedure used as the basis for comparison was a modification of the spectrophotometric method of Gorz et al. for seedling assay (2). Samples (usually $2.00 \mathrm{~g}$ ) of fresh leaf tissue were immersed in $100 \mathrm{~mL}$ of distilled water and immediately autoclaved for $30 \mathrm{~min}$ at about $120^{\circ} \mathrm{C}$. This part of the procedure was designed to rapidly inactivate tissue enzymes and to extract and hydrolyze any dhurrin present in the tissue. A $10-\mathrm{mL}$ portion of the extract was then shaken with three successive 6 - to $7-\mathrm{mL}$ portions of diethyl ether (USP grade) to remove $p$-HB. Water $(0.5 \mathrm{~mL})$ was added to the combined ether phases in a test tube, the tube was placed in a water bath at ca $55^{\circ} \mathrm{C}$, and the ether was evaporated in a gentle air stream. Evaporation was terminated as soon as the ether-water interface was reached. Water was then added to restore the volume to $10 \mathrm{~mL}$. Recovery of pure $p$-HB subjected to this treatment exceeded $90 \%$, whereas losses as great as $50 \%$ were common if the ether phase was evaporated to complete dryness. Most of the residual ether was evaporated from the aqueous phase

\footnotetext{
${ }^{1}$ Contribution from USDA-ARS and the Nebraska Agric. Exp. Stn., Lincoln, NE 68583. Published as Paper no. 7398, Journal Series, Nebraska Agric. Exp. Stn. The work reported was done under Nebraska Agric. Exp. Stn. Project 12-114. Received 6 Feb. 1984.

${ }^{2}$ George Holmes professor of agronomy; supervisory research geneticist, USDA-ARS and professor of agronomy; associate professor of agricultural biochemistry; and research technologist in agronomy, respectively.
} 
by heating in a $55^{\circ} \mathrm{C}$ bath for $1 \mathrm{~min}$ and then bubbling air through the solution for $1 \mathrm{~min}$. Original extracts, aqueous phases, and reconstituted ether phases were diluted 10 -fold with $0.1 M \mathrm{NaOH}$ and scanned from 400 to $240 \mathrm{~nm}$ in a Perkin-Elmer Lambda 3 spectrophotometer with a Model 561 recorder $^{3}$. In experiments where the ratio of tissue weight to water volume differed from the $1: 50$ ratio just described, the dilution for scanning was adjusted accordingly.

\section{RESULTS AND DISCUSSION}

\section{Assays of Fresh and Oven-dried Tissue}

The spectra shown in Fig. $1 \mathrm{~A}$ are typical of those obtained when flag leaf tissue of field-grown N32 plants was subjected to the standard assay procedure. Fresh tissue $(2.5 \mathrm{~g})$ was autoclaved in $50 \mathrm{~mL}$ of water, and 20-fold dilutions were made for these spectral scans. The spectrum of the original extract had a prominent peak near $380 \mathrm{~nm}$ and a smaller peak near $330 \mathrm{~nm}$. Ether extraction effectively removed the substance responsible for the $330-\mathrm{nm}$ peak, leaving the $380-\mathrm{nm}$ absorbing material(s) in the aqueous phase. However, the reconstituted ether phase accounted for only a small fraction of the $A_{330}$ reading of the original extract. A greatly inflated $H C N-p$ value would result from the assumption that $p$-HB was primarily responsible for the $A_{330}$ of this original extract.

A 10 -g portion of the N32 flag leaf tissue was dried at $75^{\circ} \mathrm{C}$ for $2 \mathrm{~h}$, and the dry tissue was weighed and then ground to pass a $1-\mathrm{mm}$ screen. Ground material equivalent to $2.5 \mathrm{~g}$ of fresh tissue was suspended in $50 \mathrm{ml}$ of water and incubated with occasional shaking at room temperature for $2 \mathrm{~h}$. The tissue residue was removed by filtration and discarded, and a portion of the filtrate was autoclaved for $30 \mathrm{~min}$, after which part of the autoclaved solution was extracted with ether. As shown in Fig. 1B, the spectrum of the autoclaved extract had no 380-nm peak but had a strong 330 -nm peak. The material responsible for this 330 $\mathrm{nm}$ peak was extracted with ether. The spectrum of the reconstituted ether phase resembled very closely that of pure $p-\mathrm{HB}(2)$. Calculations of HCN-p based on tissue dry weight and on the $A_{330}$ readings of the ether phases shown in Fig. 1 yielded values of 214 $\mathrm{mg} \mathrm{kg}^{-1}$ for the sample that was autoclaved without prior treatment and $681 \mathrm{mg} \mathrm{kg}^{-1}$ for the oven-dried sample, a difference of 3.2 fold. According to the values listed by Harrington (4), the $214 \mathrm{mg} \mathrm{kg}^{-1}$ level would be considered safe, but $681 \mathrm{mg} \mathrm{kg}^{-1}$ would be potentially dangerous to grazing animals. Effects similar to those described were observed repeatedly with field-grown N32 leaves. Reconstituted ether phases from autoclaved extracts of tissue dried at $75^{\circ} \mathrm{C}$ typically had $A_{330}$ values (and therefore HCN-p values) from two to five times as high as ether phases from extracts resulting from autoclaving fresh tissue.

Leaves from 10 other fall-sampled grain and forage sorghums had HCN-p values of $104 \pm 7 \mathrm{mg} \mathrm{kg}^{-1}(\overline{\mathrm{x}}$

\footnotetext{
${ }^{3}$ Mention of a trademark or proprietary product does not constitute a guarantee or warranty of the product by the USDA or the Univ. of Nebraska and does not imply its approval to the exclusion of other products that may also be suitable.
}

$\pm \mathrm{s}_{\overline{\mathrm{x}}}$, dry basis) for the standard assay and $277 \pm 39$ $\mathrm{mg} \mathrm{kg}^{-1}$ for oven-treated samples. Ratios of the second treatment to the first ranged from 1.9 to 3.8 and averaged $2.6 \pm 0.2$. By contrast, eight sudangrass entries sampled at about the same time averaged 78 \pm 7 and $9 \mathrm{l} \pm 11 \mathrm{mg} \mathrm{kg}^{-1}$, respectively, by the standard assay and the oven treatment. The ratio of the second treatment to the first for these sudangrasses ranged from 0.9 to 1.4 , with an average of $1.2 \pm$ 0.1 . Clearly the sudangrasses were lower in HCN-p than the sorghums, as expected (2), and as measured in this experiment their HCN-p levels were affected much less by the oven treatment than were HCN-p levels of sorghum.

In another series of experiments, upper leaves of field-grown N32 and KS8 were sampled at weekly intervals during the 1983 growing season. Sampling was begun 3 weeks after planting and was continued until frost had killed the leaves. The first six weekly samples consisted of blades from the youngest leaf with a readily visible collar; in some instances blades from the next one or two older leaves also were included. Beginning with the 4 August samples, flag leaves were easily identified, and samples thereafter consisted of blades from the flag leaf and the next two older leaves. Similar portions of tissue were subjected to the standard assay and to the procedure involving heating of the tissue at $75^{\circ} \mathrm{C}$ for $2 \mathrm{~h}$ prior to extraction in the autoclave. All HCN-p values were based on $A_{330}$ readings of reconstituted ether phases.

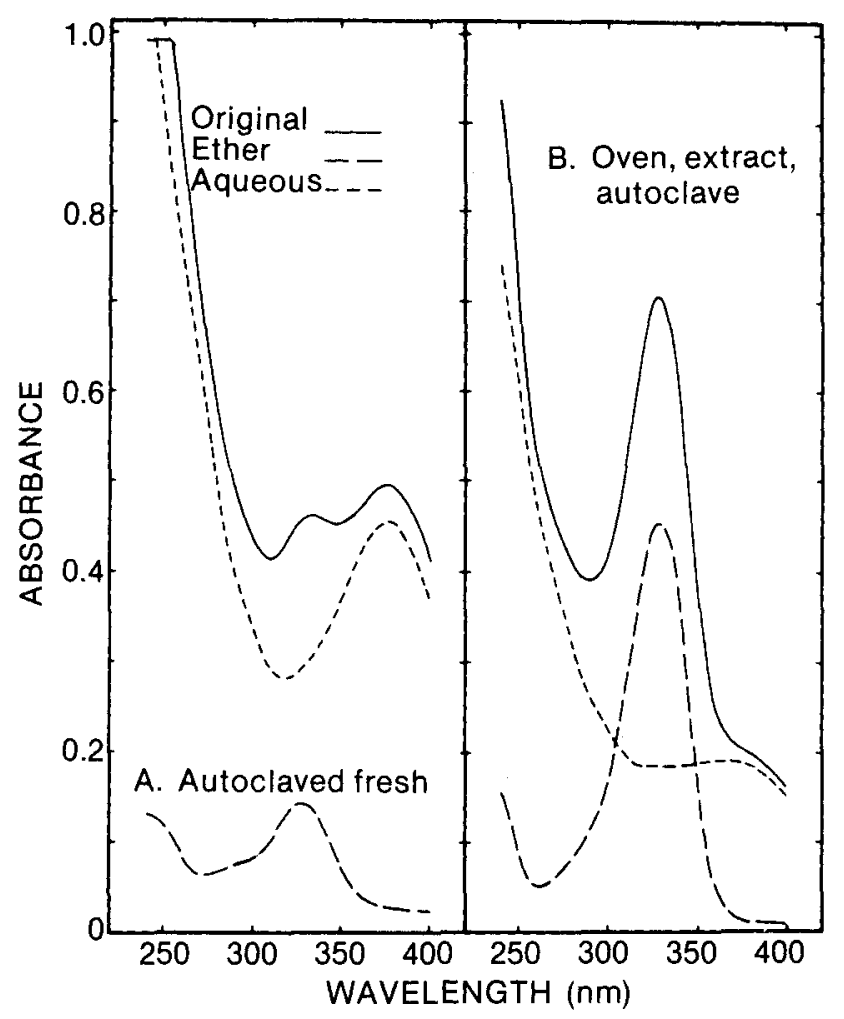

Fig. 1. Absorbance spectra of original extracts, aqueous phases, and reconstituted ether phases derived from N32 flag leaf tissue. The spectra in $A$ resulted from tissue that was autoclaved without prior treatment; those in $B$ were based on tissue that was dried at $75^{\circ} \mathrm{C}$, ground, and extracted at room temperature after which the extract was autoclaved. 
As shown in Fig. 2, for the first two sampling dates HCN-p values for KS8 were higher than those for similarly treated N32, and the oven treatment produced considerably higher readings than the standard assay for both entries. Beginning with the 7 July samples HCN-p values for KS8 were very low, and oven treatment of KS8 leaf tissue had relatively little effect on these values. The behavior of these KS8 samples resembled that of the sudangrass samples mentioned in the preceding paragraph, perhaps because KS8 was derived in part from a sudangrass. Values for N32 were consistently higher than those for KS8, and the effect of oven treatment of N32 tissue was pronounced for all samples taken before frost, which occurred on 23 September. Correlations of values obtained by the two methods over the 16 week period were highly significant $(r=0.99 * *$ for KS8 and $0.85^{* *}$ for N32, significant at the 0.01 level). Mean ratios of values based on oven-dried tissue to those for tissue autoclaved without drying were 1.6 \pm 0.1 for KS 8 and $3.2 \pm 0.3$ for N32.

\section{Possible Explanations of Apparent HCN-p Enhancement}

1. When oven-dried tissue is autoclaved in water, dhurrin may be extracted and hydrolyzed more completely than when fresh tissue is autoclaved. In an experiment to test this possibility, two 2.0 -g samples

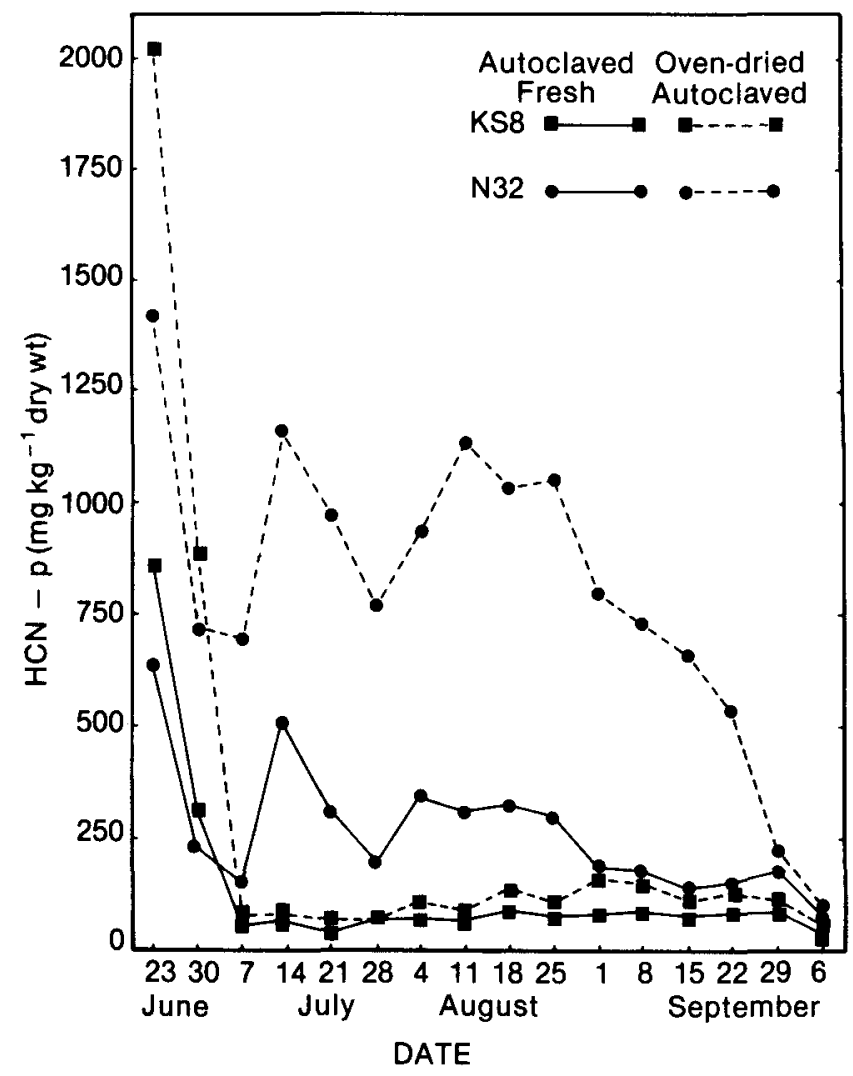

Fig. 2. Hydrocyanic acid potential (HCN-p) of upper leaves of field-grown plants of KS8 and N32 harvested at weekly intervals in 1983. Planting date was 2 June; upper leaves were frosted on 23 September. A portion of each fresh sample was autoclaved, and another portion was dried at $75^{\circ} \mathrm{C}$ prior to autoclaving. All HCN-p values were based on $A_{330}$ readings of reconstituted ether phases. of N32 leaf blade tissue were autoclaved in $100 \mathrm{~mL}$ of water as in the standard assay. Two other $2.0-\mathrm{g}$ portions were dried for $2 \mathrm{~h}$ at $75^{\circ} \mathrm{C}$ before they were autoclaved. All extracts were decanted, and tissue residues were immersed briefly in water which was then decanted and discarded. Washed residues were resuspended in $50 \mathrm{~mL}$ of water and autoclaved for an additional $30 \mathrm{~min}$. Portions of all first and second extracts were partitioned with ether, and spectra of the reconstituted ether phases were scanned. Peaks at $330 \mathrm{~nm}$ were observed in all of these scans, but these peaks were much less clean in scans of second than in those of first extracts. The sum of both extracts of autoclaved fresh tissue indicated an average HCN-p of $376 \mathrm{mg} \mathrm{kg}^{-1}$ (dry basis), 92\% of which was in the first extract. In comparison oven-treated tissue had an average HCN-p of $1023 \mathrm{mg} \mathrm{mg}-1,96 \%$ of which was in the first extract. The small difference in effectiveness of first extraction (92\% compared to $96 \%)$ failed to account for the large treatment difference in $\mathrm{HCN}-\mathrm{p}$. Reautoclaving an extract of fresh leaves produced only a very small increase in $\mathrm{HCN}$ $\mathrm{p}$; thus a single 30 -min autoclaving appeared adequate to hydrolyze the dhurrin that was present. These observations suggest that the effect of drying at $75^{\circ} \mathrm{C}$ is not merely the result of enhanced extraction or hydrolysis of dhurrin.

2. Based on the appearance of the spectra in Fig. 1 , it might be speculated that the substance responsible for the $380-\mathrm{nm}$ peak in extracts of leaf tissue subjected to the standard assay (Fig. 1A) was converted to a substance with a 330 -nm peak when the tissue was oven-dried. Conversely, the substance responsible for the 330-nm peak in the oven-treated sample (Fig. 1B) might, if the tissue were autoclaved fresh, be converted to a $380 \mathrm{~nm}$-absorbing substance. No support was found for either of these possibilities, for no consistent relationship between $A_{380}$ and $A_{330}$ values was observed in samples taken throughout the season.

In addition, further analysis of the extract that was autoclaved to provide the scans shown in Fig. $1 \mathrm{~B}$ provided strong evidence that the $330-\mathrm{nm}$ peak did not result from conversion of some unidentified compound with a $380-\mathrm{nm}$ peak but resulted instead from the hydrolysis of dhurrin. A nonautoclaved portion of this extract was extracted with ether and aliquots of the original extract, ether phase (reconstituted), and aqueous phase were diluted 20 -fold in $0.1 \mathrm{M}$ $\mathrm{NaOH}$ and scanned immediately. The basic solutions were then allowed to stand for about $4 \mathrm{~h}$ at room temperature after which they were again scanned. As shown in Fig. 3, the ether phase had very little absorbance and no 330-nm peak, either initially or after $4 \mathrm{~h}$ in base. Scans of the original extract and the aqueous phase each had an initial maximum at about $260 \mathrm{~nm}$, quite close to the $255-\mathrm{nm}$ peak that is characteristic of dhurrin in base (8). After $4 \mathrm{~h}$ in base both the original extract and the aqueous phase had lost the 260-nm peak, and each had developed a strong peak at $330 \mathrm{~nm}$. These observations indicate that dhurrin withstood the oven treatment and incubation in water at room temperature. Upon ether extraction, dhurrin, which is not ether-soluble, remained in the aqueous phase. Hydrolysis of dhurrin occurred 
readily when the solution was diluted in $0.1 M \mathrm{NaOH}$ (8). The gain in $A_{330}$ during alkaline hydrolysis of the original extract was approximately equal to the $A_{330}$ of the ether phase obtained after the dhurrin was hydrolyzed by autoclaving (compare Fig. 3 and 1B). These results indicate that dhurrin was hydrolyzed, both by autoclaving in water and by treatment with alkali, to produce $p$-HB which was responsible for the spectral peak at $330 \mathrm{~nm}$.

3. Perhaps the observed differences in HCN-p resulted from differential effects of autoclaving and

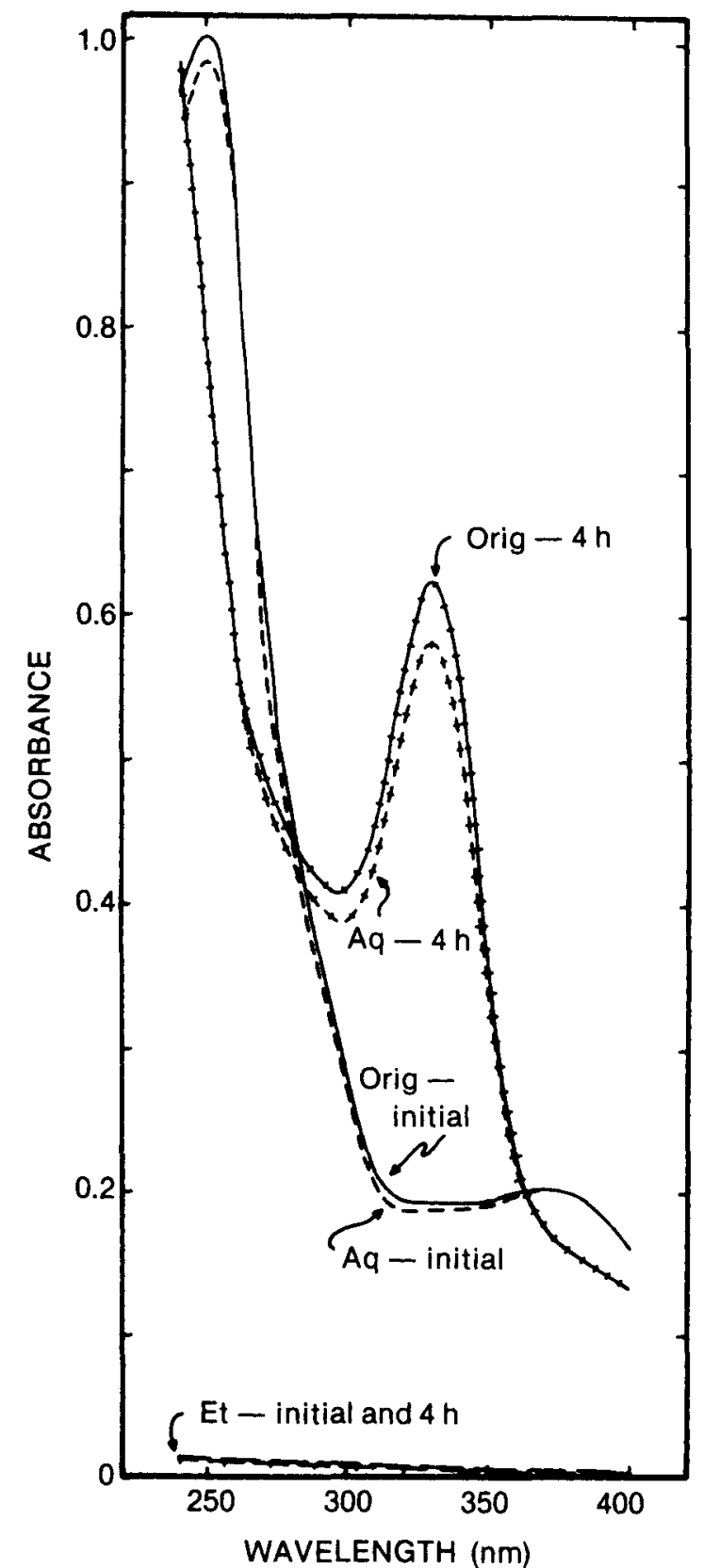

Fig. 3. Absorbance spectra resulting from alkaline hydrolysis of an original extract (Orig) and corresponding aqueous (Aq) and reconstituted ether $(\mathrm{Et})$ phases. The original extract was obtained by drying $N 32$ flag leaf tissue at $75^{\circ} \mathrm{C}$, grinding the tissue, and extracting with water at room temperature. Spectra were scanned immediately and $4 \mathrm{~h}$ after the solutions were diluted in $0.1 \mathrm{M} \mathrm{NaOH}$. heating at $75^{\circ} \mathrm{C}$ upon the activities of endogenous enzymes. To investigate this possibility, samples of N32 flag leaves were subjected to treatments that were expected to permit varying degrees of enzyme activity (Table 1). Treatments 1 and 5 , in which fresh or freeze-dried tissue was autoclaved, provided the least opportunity for enzyme activity, and these two treatments yielded the lowest $\mathrm{HCN}-\mathrm{p}$ values. However, the HCN-p value for Treatment 4 was no greater than those for Treatments 2 or 3 even though Treatment 4 should have allowed more extensive enzyme activity than the other two treatments. Similarly Treatment 6 should have allowed greater enzyme activity than Treatment 7 , yet $H C N$-p values following those two treatments were equal. These results, and similar results obtained in other experiments, indicated that differential activities of endogenous enzymes did not adequately account for the observed differences in $\mathrm{HCN}-\mathrm{p}$.

Except for Treatments 1 and 5, all of the treatments listed in Table 1 resulted in the extraction of intact dhurrin. Table 1 shows $H C N-p$ values based on $A_{330}$ readings of the reconstituted ether phases following hydrolysis of dhurrin by autoclaving, and also values based on the gain in $\mathrm{A}_{330}$ when the dhurrin was hydrolyzed in $0.1 \mathrm{M} \mathrm{NaOH}$ for $4 \mathrm{~h}$ (see Fig. 3 for example). In this experiment the latter values ranged from 87 to $95 \%$ of the former. The concentration of the extract during hydrolysis in base had a large effect on $\mathrm{HCN}$-p values calculated from $\mathbf{A}_{330}$ gain; higher HCN-p values resulted from the use of less concentrated extracts (data not shown). We have also observed that when sucrose or glucose (final concentration 0.3 to $3 \mathrm{~g} \mathrm{~L}^{-1}$ ) was added to dhurrin-containing extracts which were then made basic, appreciable loss of dhurrin occurred without the concomitant appearance of $p$-HB. Similar concentrations of glycine did not produce this effect. The influence of extract concentration on the alkaline hydrolysis of dhurrin may be related to the sugar content of the extract, but the relationship of sugar or extract concentration to the HCN-p of autoclaved and ovendried leaves is not clear.

4. Autoclaving of the fresh leaf tissue in water may have led to the destruction or alteration of dhurrin. If so, the changes did not lead to $p$ - $\mathrm{HB}$ formation, and the conditions required for these changes were

Table 1. Effects of various treatments on the hydrocyanic acid potential (HCN-p) of N32 sorghum flag leaf tissue.

\begin{tabular}{|c|c|c|}
\hline \multirow[b]{2}{*}{ Treatment } & \multicolumn{2}{|c|}{ HCN-p (mg kg ${ }^{-1}$ dry wt.) based on } \\
\hline & $\begin{array}{c}A_{9 s 0} \text { of ether } \\
\text { phase from } \\
\text { autoclaved } \\
\text { extract }\end{array}$ & $\begin{array}{l}\text { 4-h gain in } \mathrm{A}_{930} \\
\text { of orig. extr. } \\
\text { after dilution } \\
\text { in } 0.1 \mathrm{M} \mathrm{NaOH}\end{array}$ \\
\hline 1. Tissue autoclaved fresh & 214 & -- \\
\hline 2. $75^{\circ} \mathrm{C} 2 \mathrm{~h}$, grind, extract at RT $\dagger$ & 681 & 650 \\
\hline $\begin{array}{l}\text { 3. Freeze } 2 \mathrm{~h}, 75^{\circ} \mathrm{C} 2 \mathrm{~h} \text {, grind, extract } \\
\text { at RT }\end{array}$ & 638 & 603 \\
\hline 4. Freeze $2 \mathrm{~h}, \mathrm{RT} 2 \mathrm{~h}, 75^{\circ} \mathrm{C} 2 \mathrm{~h}$, grind, & 030 & 003 \\
\hline extract at RT & 603 & 556 \\
\hline 5. Freeze $2 \mathrm{~h}$, freeze dry, grind, autoclave & 350 & -- \\
\hline $\begin{array}{l}\text { 6. Freeze } 2 \mathrm{~h} \text {, freeze dry, grind, } \\
\text { extract at } R \mathrm{~T}\end{array}$ & 650 & 564 \\
\hline $\begin{array}{l}\text { 7. Freeze } 2 \mathrm{~h} \text {, freeze dry, } \mathrm{grind}, 75^{\circ} \mathrm{C} 2 \mathrm{~h} \text {, } \\
\text { extract at RT }\end{array}$ & 650 & 599 \\
\hline
\end{tabular}

$\dagger \mathrm{RT}=$ room temperature 
no longer met if the tissue was first subjected to heating at $75^{\circ} \mathrm{C}$, or freezing followed by incubation at room temperature, etc. Recovery experiments supported this interpretation. Young leaves of KS8 and N32 plants that were nearing or just beginning head emergence were used in two recovery experiments. Samples of fresh leaf blade tissue and of dried $\left(75^{\circ} \mathrm{C}\right.$, $2 \mathrm{~h}$ ) and ground tissue were autoclaved in water and also in an extract of young sorghum seedlings containing dhurrin equivalent to a $p$-HB concentration of $24 \mathrm{mg} \mathrm{L}^{-1}$. Ether extraction was performed as usual. If recovery were complete, the ratio of the $\mathrm{A}_{\mathbf{3 3 0}}$ resulting from autoclaving the tissue in the seedling extract to the sum of the $A_{330}$ for the leaf extract plus that for the seedling extract should equal 1.00. Observed values for this ratio (mean of the two experiments \pm SE) for KS8 were $0.41 \pm 0$ for the sample autoclaved while fresh and $0.77 \pm 0.02$ for the oven-treated sample. Corresponding values for $\mathrm{N} 32$ were $0.79 \pm 0.05$ and $0.88 \pm 0.03$. Enhancement ratios (mean HCN-p for oven treated sample divided by mean HCN-p for sample autoclaved fresh) were $(86 \pm 20) \div(82 \pm 9)=1.05$ for KS8 and $(857$ $\pm 80) \div(324 \pm 41)=2.65$ for N32. If differences in recovery were a major factor in explaining differences in apparent HCN-p enhancement, one would expect large treatment differences in recovery to be accompanied by large differences in HCN-p. The data indicated, however, that N32, for which apparent enhancement was large, displayed only small effects of oven-drying on recovery; whereas recovery differences due to treatment were large and enhancement was small for KS8.

Although differences in recovery as measured in these experiments did not adequately account for the observed enhancement effects, the recovery experiments did not rule out dhurrin alteration as a possible factor in these effects. Some cyanogenic glycosides undergo alteration by epimerization when heated in aqueous solution (9). However, both dhurrin and its epimer, taxiphyllin [ $p$-hydroxy-(R)-mandelonitrile- $\beta$ D-glucoside], are degraded to glucose, HCN, and $p$ $\mathrm{HB}$ when heated in water (9), and interconversion of the epimers should not result in any loss in their degradation products. This type of alteration, therefore, does not provide a reasonable explanation for the observed differences between autoclaved and ovendried samples.

5. It is conceivable that the apparent differences in HCN-p between oven-treated samples and those autoclaved while fresh may be an artifact of the spectrophotometric procedure, in which cyanide content is only indirectly determined. To assess this possibility, samples were extracted as in the AOAC procedure for cyanide determination (1), and distillates were caught in $0.1 \mathrm{M} \mathrm{NaOH}$. These distillates were then assayed for cyanide by the colorimetric procedure of Lambert et al. (7) as modified in the laboratory of Dr. E. E. Conn, University of California, Davis (personal communication) or by use of a cyanide electrode. The residual suspensions in the boiling flasks were restored to the original volume and filtered, and portions of the filtrates were extracted with ether to provide solutions for scanning and calculation of $\mathrm{HCN}-\mathrm{p}$ based on $\mathrm{A}_{330}$ values. Boiling for $30 \mathrm{~min}$ during distillation effected virtually complete hydrolysis of dhurrin, and $p$-HB did not appear in the distillate in appreciable quantity in this procedure. Some samples were homogenized in near-boiling water and distilled immediately to provide conditions similar to those existing when fresh leaves were autoclaved; other samples were dried at $75^{\circ} \mathrm{C}$ or dried and ground prior to distillation. A total of 31 comparisons were made in various experiments. Values based on determination of cyanide in the distillates were consistently higher than those based on $A_{330}$ readings of the ether extracts from the residual solutions. For the 31 comparisons, the mean ratio of the former to the latter was $1.31 \pm 0.02$. That this ratio was greater than unity was probably due in part to loss of $p$-HB during ether extraction. Previous work indicated a recovery of about $90 \%$ during this extraction (5).

Although values based on cyanide and $p$-HB determination did not agree completely, they were highly correlated ( $r$ for the 31 pairs of values was 0.99**), and enhancement ratios derived from the two types of determination were similar. We conclude that the observed difference in HCN-p between oven-treated samples and those autoclaved while fresh was not caused by any peculiarity of the spectrophotometric method.

\section{CONCLUSIONS}

Autoclaving leaves of field-grown sorghum plants caused the alteration or loss of dhurrin without yielding $p$-HB or HCN. To reduce or eliminate this loss, we suggest that when procedures involving boiling of the tissue as in the method of Harrington (4) or autoclaving the tissue as in the spectrophotometric method (2) are to be used, the tissue should first be given a preliminary treatment such as drying at $75^{\circ} \mathrm{C}$ or freezing, thawing, and incubating at room temperature. Harrington does not indicate whether a pretreatment was applied to the tissue that he subjected to distillation. It seems possible, however, that what has been described as a frost-effected increase in HCN-p (4) may have been due to the assay procedures used rather than to true differences in $\mathrm{HCN}$ p. For example, if the tissue harvested before frost had been oven-dried before extraction, its HCN-p might have been at least as high as that of frosted tissue, as illustrated in Fig. 2 for N32.

The effects of oven-drying shoots of chambergrown seedlings were much less pronounced than those observed for field-grown leaves. Numerous comparisons of fresh and oven-dried leaves of 7-day seedlings by the spectrophotometric method indicated that the dried leaves were generally somewhat higher in HCN-p than leaves autoclaved while fresh, but differences did not approach the two- to five-fold range encountered with field-grown N32 leaves. The spectrophotometric procedure without the additional steps of oven drying and ether extraction still appears to be satisfactory for use with young seedlings.

\section{REFERENCES}

1. Association of Official Agricultural Chemists. 1945. Methods of analysis, 6 th ed. Association of Official Agricultural Chemists. Washington, D.C. 
2. Gorz, H.J., W.L. Haag, J.E. Specht, and F.A. Haskins. 1977. Assay of $p$-hydroxybenzaldehyde as a measure of hydrocyanic acid potential in sorghums. Crop Sci. 17:578-582.

3. ----, F.A. Haskins, and K.P. Vogel. 1982. Divergent selection for hydrocyanic acid potential in sudangrass. Crop Sci. 22:322325 .

4. Harrington, J.D. 1966. Hydrocyanic acid content of Piper, Trudan I, and six sorghum-sudangrass hybrids. Pennsylvania State Univ. Agric. Exp. Stn. Bull. 735.

5. Haskins, F.A., H.J. Gorz, and R.B. Clark. 1982. Influence of radiation level on apparent hydrocyanic acid potential of sorghum seedlings. Crop Sci. 22:101-105.

6. - _- drocyanic acid potential of Sorghum seedlings and tillers. Agron. J. 71:501-504.
7. Lambert, J.L., J. Ramasamy, and J.V. Paukstelis. 1975. Stable reagents for the colorimetric determination of cyanide by modified König reactions. Anal. Chem. 47:916-918.

8. Mao, C.H., and L. Anderson. 1965. Cyanogenesis in Sorghum vulgare. II. Mechanism of the alkaline hydrolysis of dhurrin ( $p$-hydroxymandelonitrile glucoside). J. Org. Chem. 30:603607 .

9. Nahrstedt, A. 1981. Isolation and structure elucidation of cyanogenic glycosides. p. 145-181. In B. Vennesland, E.E. Conn, C.J. Knowles, J. Westley, and F. Wissing (ed.) Cyanide in biology. Academic Press, London.

10. Ross, W.M., A.J. Casady, J.R. Lawless, and F.L. Barnett. 1972. 29 Sorghum parental lines. Crop Sci. 12:722.

11. ---, H.J. Gorz, F.A. Haskins, and O.J. Webster. 1980. Registration of ten sorghum parental lines. Crop Sci. 20:834. 